\title{
Emotional Intelligence and Self-Regulated Learning towards English Examination Stress: A Comparative Study between Primary and Secondary School Students
}

\author{
Mohd Rustam Mohd Rameli ${ }^{1, *}$, Sharmilla Sinivashom ${ }^{2}$ \\ ${ }^{1}$ School of Education, Universiti Teknologi Malaysia, Malaysia \\ ${ }^{2}$ Sekolah Jenis Kebangsaan (Tamil) Masai, Johor, Malaysia
}

Received January 22, 2020; Revised April 1, 2020; Accepted April 21, 2020

Copyright $\odot 2020$ by authors, all rights reserved. Authors agree that this article remains permanently open access under the terms of the Creative Commons Attribution License 4.0 International License

\begin{abstract}
English Examination stress is becoming an alarming issue to most of Malaysian students nowadays. There are hardly any documented records of studies on influence of emotional intelligence and self-regulated learning towards English examination stress faced by the students. The major purpose of this study is to investigate the influence of emotional intelligence and self-regulated learning towards English examination stress among primary and secondary school students in Pasir Gudang District, Johor. The research design applied in this study was quantitative approach. The instruments used in this study were Wong and Law Emotional Intelligence Scale (WLEIS), Self-regulation formative questionnaire and Examination Stress Scale (ExamSS). The respondents were 334 Year Four students and 388 Form Four students from Pasir Gudang District. Results in linear regression analysis revealed that the self-regulated learning significantly contributing $4.4 \%$ in primary and $13.7 \%$ in secondary towards examination stress. Meanwhile, the multiple regression showed that, only self-regulated learning was more significant towards examination stress. The present study contributes to an understanding of the relationship and impact of self-regulated learning towards English examination stress.
\end{abstract}

Keywords Emotional Intelligence, Self-Regulated Learning, English Examination Stress, Primary School Students, Secondary School Students

\section{Background of Study}

The Malaysian education system considered public examinations as one of the important feature. In Malaysian Education System, English is taught as a second language in primary and secondary schools. Most of Malaysian students do not have interest in learning English. Malaysian students are still inhibited by social factors including lack of motivation and lack of interest to learn English ${ }^{1}$. Moreover, for second or foreign language learners, L2 or foreign language exams is very anxiety provoking causing the learners to be reluctant to score good results. Students get stress when they sit for English examinations. The dominant form of examinations in Malaysia makes the students undergo stress.

Emotional Intelligence plays a significant role in students' academic performances. Such characteristic helps students to be more efficient in their studies and reduce examination stress among students. The recent research shows that emotional intelligence is the best method to manage stressful situations ${ }^{2}$. EI is the ability to manage and use emotions in beneficial ways. EI is a set of abilities that enable individuals to organize and manage the emotions of themselves and others. Currently, teachers instil EI skill among students from both primary and secondary schools through their $21^{\text {st }}$ century learning method. There is a strong correlation between students' EI and their academic achievement in the both level of schools.

Self- regulated learning is a self- directive process where students transform their mental abilities into task-related academic skills. According to self-regulation is about the actions and thoughts on attaining goals ${ }^{3}$. Students are aware of their learning activities, they are conscious of their strengths and weaknesses. SRL students able to set up their own goals and learning strategies based on their strengths such as time table to manage their learning time proactively. Nevertheless, students can't be able to become self-regulated by themselves. SRL is shaped by numerous and diverse learning experience is different schools. Hence, there is a need to examine the level of SRL towards 
examination stress in both primary and secondary schools.

A lot of previous researches studied about examination stress but most of the researches included other variables than emotional intelligence and self-regulated learning which are anxiety ${ }^{4}$, changes in mood and health behaviour ${ }^{5}$ and self-control. However, there is no study on the examining EI and SRL simultaneously towards examination stress particularly in Malaysia context. Besides, the past studies are limited to show the relationship between EI and SRL towards English examination comparing both primary and secondary schools. Furthermore, the level of EI and SRL are different among age. This study helps to determine the influence of EI and SRL on English examination stress among year five and form four students. Therefore, this research is aimed to close the gap on the issue of the influence of emotional intelligence and self-regulated learning skills towards reducing English examination stress among Year Five and Form Four students in Pasir Gudang district.

\section{Research Objectives}

The main objective of the study is to determine the influence of emotional intelligence and self-regulated learning towards English examination stress among school students. Besides, this study will also determine the influence of students' emotional intelligence towards English examination stress and self-regulated learning towards English examination stress among school students.

\section{Methodology}

The research design of this study takes the form of the quantitative research approach. Statistical analysis of numerical data was done to deduct a conclusion to explain the issue. This research study was administered in 3 primary schools and 3 secondary schools in Pasir Gudang district of Johor state. This research applied stratified simple random sampling to determine the population samples. 354 primary school students of Year 5 and 365 secondary school students of Form 4 had been randomly selected as the samples of the study. The first section of the questionnaire is demographic information. This section consists of four questions that determine the demographic information of the respondents. The second section of the questionnaire is Wong and Law Emotional Intelligence Scale (WLEIS) which measures four dimensions namely Self emotional appraisal, others' emotional appraisal, use of emotion and regulation of emotion ${ }^{6}$.

The second instrument that used to measure self-regulation level in facing English examination among Standard Five and Form Four students is Self-regulation formative questionnaire by Gaumer Erickson and Noonan. This item measures three dimensions such as plan, control and reflect. Meanwhile, the third instrument that used to measure examination stress was Examination Stress Scale (ExamSS).

\section{Findings}

Table 1 showed the linear regression analysis between emotional intelligence and examination stress in primary school. The independent variable of this hypothesis is emotional intelligence and the dependent variable is examination stress. Based on the data derived, $13.9 \%$ of influence of emotional intelligence towards examination stress. Table 1 , shows the significance value is 0.011 which is lesser than the value of alpha, 0.05 .

Table 1. Linear Regression Analysis between emotional intelligence and examination stress in primary school

\begin{tabular}{|c|c|c|c|c|c|}
\hline \multicolumn{6}{|c|}{ Model Summary } \\
\hline Model & \multicolumn{2}{|l|}{$\mathrm{R}$} & R Square & Adjusted R Square & Std. Error of the Estimate \\
\hline 1 & \multicolumn{2}{|c|}{$.139 \mathrm{a}$} & .019 & .016 & .579 \\
\hline \multicolumn{6}{|c|}{ ANOVA(a) } \\
\hline Model & Sum of Squares & df & Mean Square & $\mathrm{F}$ & Sig. \\
\hline $\begin{array}{c}\text { Regression Residual } \\
\text { Total }\end{array}$ & $\begin{array}{c}2.185 \\
111.235 \\
113.420 \\
\end{array}$ & $\begin{array}{c}1 \\
332 \\
333 \\
\end{array}$ & $\begin{array}{c}2.185 \\
.335\end{array}$ & 6.522 & $.011 b$ \\
\hline \multicolumn{6}{|c|}{ Coefficients (a) } \\
\hline \multirow{2}{*}{ Model } & \multicolumn{2}{|c|}{ Unstandardized Coefficients } & Standardized Coefficients & \multirow{2}{*}{$\mathrm{t}$} & \multirow{2}{*}{ Sig. } \\
\hline & B & Std. Error & Beta & & \\
\hline $\begin{array}{c}\text { (Constant) } \\
\text { Mean EI }\end{array}$ & $\begin{array}{l}2.525 \\
.153 \\
\end{array}$ & $\begin{array}{l}.216 \\
.060 \\
\end{array}$ & .139 & $\begin{array}{c}11.673 \\
2.554\end{array}$ & $\begin{array}{l}.000 \\
.011\end{array}$ \\
\hline
\end{tabular}


Table 2 showed the linear regression analysis between emotional intelligence and examination stress in secondary school. The independent variable, emotional intelligence $(\beta=0.186, p<0.05)$ is significant predictor of examination stress. The result also states that emotional intelligence contributes $3.2 \%[\mathrm{~F}(1,386)=13.098, \mathrm{p}<0.05], \mathrm{r}=0.186$ changes of variance in examination stress.

Table 2. Linear Regression Analysis between emotional intelligence and examination stress in secondary school

\begin{tabular}{|c|c|c|c|c|}
\hline \multicolumn{5}{|c|}{ Model Summary } \\
\hline Model & $\mathrm{R}$ & R Square & Adjusted R Square & $\begin{array}{l}\text { Std. Error of the } \\
\text { Estimate }\end{array}$ \\
\hline 1 & $.186 a$ & .035 & & .482 \\
\hline \multicolumn{5}{|c|}{ ANOVA(a) } \\
\hline Model & $\begin{array}{l}\text { Sum of } \\
\text { Squares }\end{array}$ & df & $\mathrm{F}$ & Sig. \\
\hline $\begin{array}{c}\text { Regression Residual } \\
\text { Total }\end{array}$ & $\begin{array}{c}3.226 \\
89.589 \\
92.815\end{array}$ & $\begin{array}{c}1 \\
386 \\
387\end{array}$ & 13.898 & $.000 b$ \\
\hline \multicolumn{5}{|c|}{ Coefficients (a) } \\
\hline \multirow[t]{2}{*}{ Model } & \multicolumn{2}{|c|}{ Unstandardized Coefficients } & \multirow[t]{2}{*}{$\mathrm{t}$} & \multirow[t]{2}{*}{ Sig. } \\
\hline & B & Std. Error & & \\
\hline $\begin{array}{r}\text { (Constant) } \\
\text { Mean EI }\end{array}$ & $\begin{array}{r}2.619 \\
.187 \\
\end{array}$ & $\begin{array}{l}.175 \\
.050\end{array}$ & $\begin{array}{c}14.935 \\
3.728 \\
\end{array}$ & $\begin{array}{l}.000 \\
.000 \\
\end{array}$ \\
\hline
\end{tabular}

Table 3 showed the linear regression analysis between self-regulated learning and examination stress in primary school. The independent variable, emotional intelligence $(\beta=0.217, p<0.05)$ is significant predictor of examination stress. The result also states that self-regulated learning contributes $4.4 \%[\mathrm{~F}(1,332)=16.337, \mathrm{p}<0.05], \mathrm{r}=0.217$ changes of variance in examination stress.

Table 3. Linear Regression Analysis between self-regulated learning and examination stress in primary school

\begin{tabular}{|c|c|c|c|c|c|c|}
\hline \multicolumn{7}{|c|}{ Model Summary } \\
\hline Model & $\mathrm{R}$ & \multicolumn{2}{|c|}{ R Square } & \multicolumn{2}{|c|}{ Adjusted R Square } & Std. Error of the Estimate \\
\hline 1 & $.217 \mathrm{a}$ & \multicolumn{2}{|c|}{.047} & \multicolumn{2}{|c|}{.044} & .571 \\
\hline \multicolumn{7}{|c|}{ ANOVA(a) } \\
\hline Model & Sum of Squares & df & \multicolumn{2}{|c|}{ Mean Square } & $\mathrm{F}$ & Sig. \\
\hline $\begin{array}{c}\text { Regression } \\
\text { Residual } \\
\text { Total }\end{array}$ & $\begin{array}{c}5.310 \\
108.101 \\
113.420\end{array}$ & $\begin{array}{c}1 \\
332 \\
333\end{array}$ & \multicolumn{2}{|c|}{$\begin{array}{c}5.319 \\
.326\end{array}$} & 16.337 & $.000 b$ \\
\hline \multicolumn{7}{|c|}{ Coefficients (a) } \\
\hline \multirow{2}{*}{ Model } & \multicolumn{2}{|c|}{ Unstandardized Coefficients } & \multicolumn{2}{|c|}{ Standardized Coefficients } & \multirow{2}{*}{$\mathrm{t}$} & \multirow{2}{*}{ Sig. } \\
\hline & B & Std. Error & \multicolumn{2}{|c|}{ Beta } & & \\
\hline $\begin{array}{l}1 \text { (Constant) } \\
\text { Mean SRL }\end{array}$ & $\begin{array}{c}2.181 \\
.263\end{array}$ & $\begin{array}{l}.223 \\
.065\end{array}$ & \multicolumn{2}{|c|}{.217} & $\begin{array}{l}9.800 \\
4.042\end{array}$ & $\begin{array}{l}.000 \\
.000\end{array}$ \\
\hline
\end{tabular}

Table 4 showed the linear regression analysis between self-regulated learning and examination stress in secondary school. The independent variable, emotional intelligence $(\beta=0.373, p<0.05)$ is significant predictor of examination stress. The result also states that self-regulated learning contributes $13.7 \%[\mathrm{~F}(1,386)=62.554, \mathrm{p}<0.05], \mathrm{r}=0.373$ changes of variance in examination stress. 
Table 4. Linear Regression Analysis between self-regulated learning and examination stress in secondary school

\begin{tabular}{|c|c|c|c|c|c|c|}
\hline \multicolumn{7}{|c|}{ Model Summary } \\
\hline Model & $\mathrm{R}$ & \multicolumn{2}{|c|}{ R Square } & \multicolumn{2}{|c|}{ Adjusted R Square } & Std. Error of the Estimate \\
\hline 1 & $.373 a$ & \multicolumn{2}{|c|}{.139} & \multicolumn{2}{|c|}{.137} & .455 \\
\hline \multicolumn{7}{|c|}{ ANOVA(a) } \\
\hline Model & Sum of Squares & $\mathrm{df}$ & \multicolumn{2}{|c|}{ Mean Square } & $\mathrm{F}$ & Sig. \\
\hline $\begin{array}{l}\text { Regression } \\
\text { Residual } \\
\text { Total }\end{array}$ & $\begin{array}{l}12.944 \\
79.871 \\
92.815\end{array}$ & $\begin{array}{c}1 \\
386 \\
387\end{array}$ & \multicolumn{2}{|c|}{$\begin{array}{c}12.944 \\
.207\end{array}$} & 62.554 & $.000 b$ \\
\hline \multicolumn{7}{|c|}{ Coefficients (a) } \\
\hline \multirow{2}{*}{ Model } & \multicolumn{2}{|c|}{ Unstandardized Coefficients } & \multirow{2}{*}{\multicolumn{2}{|c|}{$\frac{\text { Standardized Coefficients }}{\text { Beta }}$}} & \multirow{2}{*}{$\mathrm{t}$} & \multirow{2}{*}{ Sig. } \\
\hline & $\mathrm{B}$ & Std. Error & & & & \\
\hline $\begin{array}{l}\text { (Constant) } \\
\text { Mean SRL }\end{array}$ & $\begin{array}{c}1.929 \\
.384\end{array}$ & $\begin{array}{l}.171 \\
.049\end{array}$ & & & $\begin{array}{c}11.304 \\
7.909\end{array}$ & $\begin{array}{l}.000 \\
.000\end{array}$ \\
\hline
\end{tabular}

Table 5 showed the multiple regression analysis between self-regulated learning and examination stress in primary school. At this point, the emotional intelligence is excluded from this table. Self-regulated learning is the only variable that attached in this table; $[\mathrm{F}(1,332)=16.337, \mathrm{p}<0.05], \mathrm{r}=0.217$.

Table 5. Linear Regression Analysis between self-regulated learning and examination stress in primary school

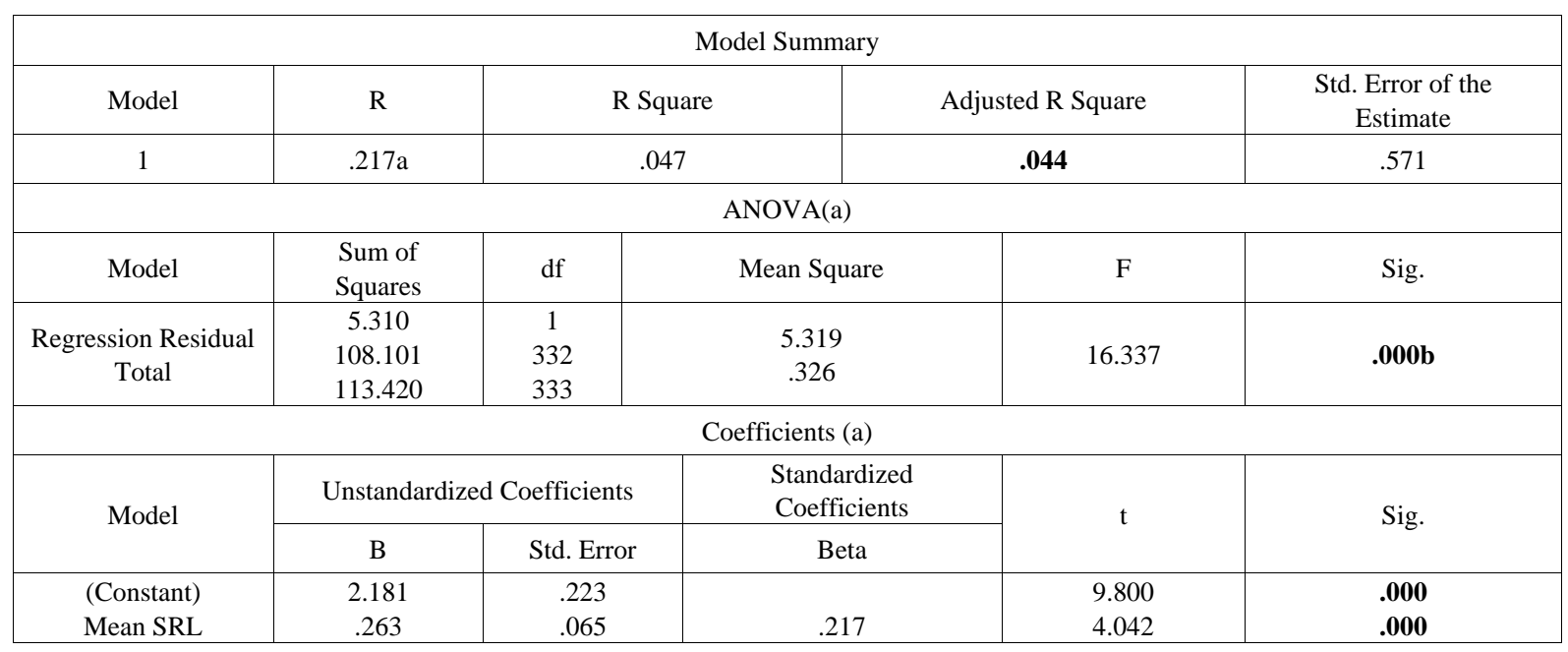

Table 6 showed the multiple regression analysis between self-regulated learning and examination stress in secondary school. At this point, the emotional intelligence is excluded from this table. Self-regulated learning is the only variable that attached in this table; $[\mathrm{F}(1,386)=62.554, \mathrm{p}<0.05], \mathrm{r}=0.373$.

Table 6. Linear Regression Analysis between self-regulated learning and examination stress in secondary school

\begin{tabular}{|c|c|c|c|c|c|c|}
\hline \multicolumn{7}{|c|}{ Model Summary } \\
\hline Model & $\mathrm{R}$ & \multicolumn{2}{|c|}{ R Square } & \multicolumn{2}{|c|}{ Adjusted R Square } & Std. Error of the Estimate \\
\hline 1 & $.373 \mathrm{a}$ & \multicolumn{2}{|c|}{.139} & \multicolumn{2}{|c|}{.137} & .455 \\
\hline \multicolumn{7}{|c|}{$\operatorname{ANOVA}(\mathrm{a})$} \\
\hline Model & Sum of Squares & $\mathrm{df}$ & \multicolumn{2}{|c|}{ Mean Square } & $\mathrm{F}$ & Sig. \\
\hline $\begin{array}{c}\text { Regression } \\
\text { Residual } \\
\text { Total }\end{array}$ & $\begin{array}{l}12.944 \\
79.871 \\
92.815 \\
\end{array}$ & $\begin{array}{c}1 \\
386 \\
387 \\
\end{array}$ & \multicolumn{2}{|c|}{$\begin{array}{c}12.944 \\
.207\end{array}$} & 62.554 & $.000 b$ \\
\hline \multicolumn{7}{|c|}{ Coefficients (a) } \\
\hline \multirow{2}{*}{ Model } & \multicolumn{2}{|c|}{ Unstandardized Coefficients } & & & \multirow{2}{*}{$\mathrm{t}$} & \multirow{2}{*}{ Sig. } \\
\hline & B & Std. Error & & & & \\
\hline $\begin{array}{l}\text { (Constant) } \\
\text { Mean SRL }\end{array}$ & $\begin{array}{c}1.929 \\
.384\end{array}$ & $\begin{array}{l}.171 \\
.049\end{array}$ & & & $\begin{array}{c}11.304 \\
7.909\end{array}$ & $\begin{array}{l}.000 \\
.000\end{array}$ \\
\hline
\end{tabular}




\section{Discussion}

\subsection{Influence of Emotional Intelligence towards English Examination Stress among school students}

According to data analysis, the influence of emotional intelligence towards English examination stress among school students is significant. Linear regression analysis was conducted for this objective. The results show that the influence of emotional intelligence towards English examination stress among secondary school students are more significant compared to primary school students. It brought to the limelight that emotional intelligence influenced secondary students more than primary school student. Besides, secondary school students are more mature enough to acquire EI skill when facing examination stress compare to primary level students.

Based on previous studies, students with higher emotional intelligence skills less likely undergo examination stress. For instance, students with higher level of emotional intelligence skills are less likely under pressure, anxious and having the higher level of self-confidence and positive vibes. EI students acquire problem solving skills in their life ${ }^{2}$. They able to control and manage their emotions and project in smart way where they could handle English examinations well. EI students well verse in controlling pressure and manages their impulses. As a result, students get motivated during English examinations and have positive thinking towards accomplishment of their goals ${ }^{7}$.

Based on the findings, the result of this linear regression of EI towards examination stress between primary and secondary schools have gave out the expected results. Secondary school students are highly organized in managing their emotions compared to primary school students. 3.2\% of EI from secondary school students significantly contributing towards English examination stress whereas $1.6 \%$ of EI contributing towards English examination stress among primary school students. The overall result of researches suggest that high EI people helps individuals to communicate better, able to reduce their anxiety and stress, build strong, healthy relationships, and able to overcome life's challenges effectively ${ }^{8}$.

\subsection{Influence of Self-Regulated Learning towards English Examination Stress among School Students}

According to data analysis, the influence of self-regulated learning towards English examination stress among school students is significant. Linear regression analysis was conducted for this objective. The results show that the influence of self-regulated learning towards English examination stress among secondary school students are more significant compared to primary school students. Thus, we can conclude that self-regulated learning influenced secondary students more than primary school student.

With SRL attitude, student will realise their learning responsibilities on what to learn, knowing the suitable methods and structure their own learning. This method helps students to manage their studies during the examination period. A good self-regulator is the one who withstand temptations, persist through obstacles and delay gratification and more likely to be more successful in their goals and life satisfaction ${ }^{6}$. As such, it emphasis on the importance of self-regulation towards students in learning.

Based on the findings, the result of this linear regression of SRL towards examination stress between primary and secondary schools have gave out the most expected results. Secondary school students are highly good in regulating their learning compared to primary school students. $13.7 \%$ of SRL from secondary school students significantly contributing towards English examination stress whereas $4.4 \%$ of SRL contributing towards English examination stress among primary school students. Moreover, based on the results secondary school students are more capable on acquiring SRL attitude compare to primary school students. Secondary students are more capable on their independent learning compare to primary school students.

\subsection{Influence between Emotional Intelligence and Self-Regulated Learning towards English Examination Stress among School Students}

Multiple regression analysis were conducted to examine the influence between Emotional Intelligence and Self-Regulated Learning towards English Examination Stress among school students. The multiple regression findings indicated that self-regulated learning was the significant predictor that influenced English examination stress among school students. On the other hand, emotional intelligence was not significant predictor of this research. This may because, SRL playing more important role in preparing students towards facing English examination stress.

Besides, through this study, the students of primary and secondary school students in Masai, Johor will know the importance of emotional intelligence learning in their studies besides self-regulated learning. Emotional intelligence brings out self- awareness among students where the students encompassing their own knowledge to themselves. They also able recognise and understand their behaviours and emotions. Thus, they able to be in control of the stress they endure during examination days. They might act as aggressive to peers, parents which lead to unhealthy relationships. Emotional intelligence creates rational thinkers where students able to understand others' feelings and help to build and maintain relationships and also get to manage conflict with others.

As a conclusion, multiple regression analysis stated that 
SRL is the only significant predictor towards English examination stress among primary and secondary school students in Pasir Gudang. Besides, secondary school students are more capable on acqiring SRL compare to primary school students due to environmental factors such as age, maturity, different learning method and etc. Thus, secondary school students are more competent on facing examination stress compare to primary school students.

\section{Source of Funding}

Fundamental Research Grant Scheme (Vot. No. RJI30000.7853.5F039).

\section{Conflict of Interest}

No

\section{Ethical Clearance}

Obtained from Ministry of Education, Malaysia
Evaluation in Counseling and Development. 2015, 48(1), 44-58.

\section{REFERENCES}

[1] Darmi R, Albion, PR. English Language in Malaysian Education System Its Existence and Implication. 3rd Malaysia Postgraduate Conference (MPC 2013), 4-5 July 2013, Sydney, Australia.

[2] Brackett M, Rivers S, Salovey P. Emotional Intelligence: Implications for Personal, Social, Academic, and Workplace Success. Social and Personality Psychology Compass. 2011, 5(1), 88-103.

[3] Cho M, Shen D. Self-regulation in online learning. Distance Education. 2013, 34(3), 290-301.

[4] Eum K, Rice K. Test anxiety, perfectionism, goal orientation, and academic performance. Anxiety, Stress \& Coping. 2011, 24(2), 167-178.

[5] Xiao J. Academic Stress, Test Anxiety, and Performance in a Chinese High School Sample: The Moderating Effects of Coping Strategies and Perceived Social Support. Scholar Works@ Georgia State University, 2013.

[6] 6LaPalme M, Wang W, Joseph D, Saklofske D, Yan G. Measurement equivalence of the Wong and Law Emotional Intelligence Scale across cultures: An item response theory approach. Personality and Individual Differences. 2016, 90, 190-198.

[7] Mason L, Harris K, Graham S. Self-Regulated Strategy Development for Students With Writing Difficulties. Theory Into Practice. 2011, 50(1), 20-27.

[8] Sung Y, Chao T. Construction of the Examination Stress Scale for Adolescent Students. Measurement and 